\title{
RHIZOBACTERIAL SWITCHING TOWARDS CLIMATE SMART AGROECOSYSTEMS
}

\author{
KAUSHAL, M. ${ }^{{ }^{*}}-$ KAUSHAL, R. ${ }^{2}$ \\ ${ }^{I}$ International Institute of Tropical Agriculture \\ Plot No. 25, Mikocheni B, Coca Cola Road, Dar es Salaam 34441, Tanzania \\ ${ }^{2}$ Department of Soil Science, Dr. Y. S. Parmar University of Horticulture and Forestry \\ Nauni, Solan, Himachal Pradesh 173230, India \\ *Corresponding author \\ email: kaushal.mbg@gmail.com \\ (Received 11 $1^{\text {th }}$ Aug 2018; accepted $4^{\text {th }}$ Oct 2018)
}

\begin{abstract}
Climate smart agriculture is defined as a systematic and synergetic ingress for transformation and reorientation of agricultural development under constrained environment with climate risks. Enhanced plant productivity and reduced microbial respiratory $\mathrm{C}$ can potentially mitigate the rising of the atmospheric $\mathrm{CO}_{2}$ however we are currently in shortfall of efficient routes to accomplish these objectives. Under future climate scenarios of exalted $\mathrm{CO}_{2}$, rhizosphere microbes may serve important links in mediating plant productivity and soil $\mathrm{C} / \mathrm{N}$ dynamics with optimization of root-soil interface mechanisms to achieve CSA goals. Study was undertaken to precisely quantify microbial biomass-carbon and microbial activity of rhizosphere region of cauliflower (Brassica oleracea var. botrytis) at two different agro-climatic zones. A native bacterial strain Bacillus pumilus isolated from cauliflower rhizosphere was employed that enhanced plant growth, nutrient uptake with improved soil nutrient status. Microbial biomass carbon (119.8 $\mathrm{mg} \mathrm{MB-C/} 100 \mathrm{~g}$ soil) was the highest with the application of Bacillus pumilus and 75\% NP fertilizers at both locations. Moreover, the microbial activity was found to be the highest ( $0.18 \mathrm{mg} \mathrm{CO}_{2} / \mathrm{g}$ soil) with the same consortium up to $48 \mathrm{~h}$ and then followed a sudden decreasing trend. The results clearly suggest that Bacillus pumilus strains as bio-inoculants can be successfully employed for maintaining soil health being useful in context of climate smart agriculture goals.

Keywords: Bacillus pumilus, microbial biomass, soil microbial activity, Pearson's correlation, principal component analysis
\end{abstract}

\section{Introduction}

The hastily growing world population which is expected to be 8.9 billion by 2050 (UN, 2015), raised an alarming situation of increasing food demand. In a study done by Center for Study of Carbon Dioxide and Global Change revealed that about 70-100\% increase in crop production is requisite to feed this consistently rising population (UN, 2015). Intensive farming, a tool of elevated yield however, promotes the use of chemical fertilizers and pesticides at peak levels with rapid existence of pests and diseases. When used frantically, these fertilizers and pesticides get accumulated in soil and in water leading to adverse impact on livestock and on human health, as well as on our ecosystem (Liu et al., 2012). Depletion of soil nutrients, diversification of croplands, genetic diversity and augmentation to global warming are the other wellknown associated obstacles of intensive agriculture. Thus, considering long-term emphasis of soil quality and fertility there is an increasing interest in the use of climate smart agritechnology that can enhance crop yield as well as ensures sustainability and resilience (Hamilton et al., 2016). Climate smart agriculture (CSA) may be defined as a synergetic approach to transform and reorient agricultural development and security 
under the horrified situation of climate change (Khatri-Chhetri et al., 2017). Sustainable productivity, enhanced resilience or adaptation and Green house gases (GHGs) mitigation are identified as the three interlinked pillars requisite to engender these agricultural food security goals. To achieve desired goals of food productivity, adaptation and GHG mitigation CSA approaches must involve the appropriate inclusion of beneficial bacteria. Revitalising soil quality is a major aspect of sustainable agriculture. Technologies like use of plant growth promoting microbes serves as a boon to crops with multifarious attributes. Despite of the restoration of soil fertility, rhizosphere microbes are lending with other perks such as stimulation of plant growth, boosting crop yield and resistance against diversified soil borne pathogens. Plant growth-promoting rhizobacteria (PGPR) can arouse plant growth by direct (fixation of nitrogen, solubilization of phosphorus etc.) or indirect (antibiosis, induction of systemic resistance etc.) mechanisms (Kaushal and Wani, 2016). Some of the common PGPR include genera Acinetobacter, Alcaligenes, Arthrobacter, Azospirillum, Azotobacter, Bacillus pumilus, Beijerinckia, Burkholderia, Enterobacter, Erwinia, Flavobacterium, Rhizobium, and Serratia (Anandaraj and Dinesh, 2008). Various studies have shown positive effects of PGPR on cereals (Shaharoona et al., 2006), fruits (Kavino et al., 2010) and vegetables (Kaushal et al., 2017) when either used alone or in combination with fertilizers for enhancing crop yields and have committed to the progress of sustainable agricultural systems. Impacts of PGPR on growth and yield parameters have been widely investigated, slight clue exists on the effects of PGPR on sensitive biochemical and microbial indices reflecting soil quality. Besides extra sensitive to environmental stress biochemical properties imparts rapid and authentic values on soil quality (Ding, 2010). The biochemical parameters comprise of the variables that are directly associated to microbial activity such as microbial biomass $\mathrm{C}$ and respiration. Microbial biomass $\mathrm{C}$ and respiration are considered as potential indicators of soil quality and management impacts (Dinesh and Ghoshal, 2013). Moreover, ameliorated microbial biomass $\mathrm{C}$ boosts plant productivity and reduced microbial respiratory $\mathrm{C}$ loss could potentially mitigate increasing atmospheric $\mathrm{CO}_{2}$ concentrations. Nevertheless, our understanding of PGPR interactions with plants to regulate microbial biomass $\mathrm{C}$ and microbial respiration in the rhizosphere is still limited. We evaluated the effect of Bacillus pumilus inoculation with reduced applications of $\mathrm{N}$ and $\mathrm{P}$ on productivity of cauliflower and soil nutrient status under North Western Himalayas. Bacillus pumilus with $75 \% \mathrm{NP}$, improves cauliflower yield (by 27.65\%) over recommended dose of fertilizers through several different mechanisms, such as enhancement of nutrient uptake and the suppression of plant diseases (Kaushal and Kaushal, 2015). Here, we hypothesized that use of PGPR along with reduced application of fertilizers (NP) would attenuate such negative impacts of sole NPK use on beneficial soil microbiota and their related functions.

Hence, the objective of the study was to figure out the impacts of Bacillus pumilus (native strains of PGPR isolated from cauliflower rhizosphere) applied with reduced application of NP fertilizers (urea and muriate of potash) on microbial biomass $\mathrm{C}$ and microbial activity $\left(\mathrm{CO}_{2}\right.$ evolution). Another objective was to determine the correlations between yield parameters of cauliflower, soil nutrient status and inoculated population of native strain impacting microbial biomass and activity. 


\section{Materials and methods}

\section{Site description}

The study was conducted at two locations (Dr. Y. S. Parmar University of Horticulture and Forestry, Nauni, Solan and Regional Horticultural Research Station, Kullu) of Himachal Pradesh that belongs to North-Western Himalayan region of India as presented in Figure 1. Experiments was replicated twice at both locations in each year 2010 and 2011. Both locations differ slightly in geographical characteristics, physico-chemical and microbiological properties of soil as presented in Table 1. Rhizosphere soil sampling was done before sowing (Mar 2010 and 2011) and after harvest (May 2010 and 2011) of field trails at both locations replicated twice. Three randomized soil samples were collected from each plot to make one composite sample (100 g) with the help of a soil augur and up to a depth of $15-20 \mathrm{~cm}$ from all the treated plots and every replicated experiment.

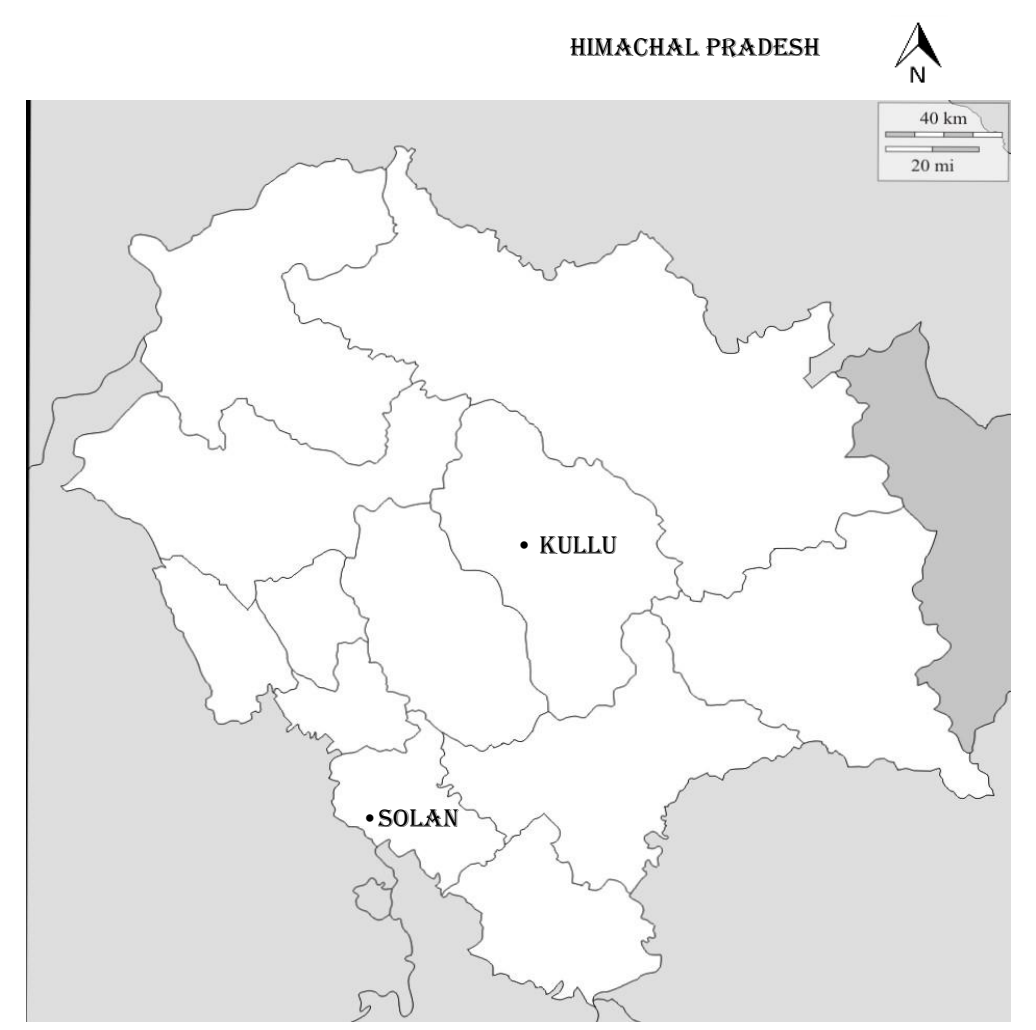

Figure 1. Study area and sampling locations of rhizospheric soil samples

\section{Plant growth promoting rhizobacterial attributes of Bacillus pumilus}

Isolated native bacterial strain from cauliflower (Brassica oleracea var. botrytis) was tested for its in vitro efficacy in ideal laboratory conditions before the field experimentations (Jan - Mar 2010) at Soil Microbiology Laboratory, Department of Soil Science and Water Management, Dr. Y S Parmar University of Horticulture and Forestry, Solan - India. Isolate was tested for major plant growth promoting attributes including P-solubilization, Indole acetic acid (IAA), siderophore and Hydrogen cyanide $(\mathrm{HCN})$ production and antagonistic activities against phytopathogens (Kaushal et al., 
2016). Nitrogen fixation ability of native bacterial strain was also quantified indirectly by acetylene reduction assay (ARA) method and compared to standard strain (procured from the Institute of Microbial Technology, Chandigarh) of Azotobacter chroococcum (Hardy et al., 1968).

Table 1. General characteristics of both locations (Solan and Kullu)

\begin{tabular}{c|c|c}
\hline Parameters/characteristics & Solan & Kullu \\
\hline Longitude & $77.0967^{\circ} \mathrm{E}$ & $77.1095^{\circ} \mathrm{E}$ \\
Latitude & $30.9045^{\circ} \mathrm{N}$ & $31.9579^{\circ} \mathrm{N}$ \\
Altitude & $1502 \mathrm{~m}$ & $1279 \mathrm{~m}$ \\
$\mathrm{pH}$ & 6.76 & 6.71 \\
Electrical conductivity $(\mathrm{EC})\left(\mathrm{dSm}^{-1}\right)$ & 0.47 & 0.34 \\
Bulk density $(\mathrm{BD})\left(\mathrm{g} \mathrm{cm}^{-3}\right)$ & 1.04 & 1.50 \\
Organic matter $(\mathrm{OM})(\%)$ & 1.16 & 1.03 \\
Nitrogen $(\mathrm{N})(\mathrm{kg} / \mathrm{ha})$ & 301.7 & 313.6 \\
Phosphorus $(\mathrm{P})(\mathrm{kg} / \mathrm{ha})$ & 41.00 & 86.00 \\
Potassium $(\mathrm{K})(\mathrm{kg} / \mathrm{ha})$ & 195.3 & 191.7 \\
\hline Total microbial counts & 185.67 & 107.00 \\
\hline
\end{tabular}

\section{Field efficacy of Bacillus pumilus inoculation}

Based on in vitro plant growth promoting traits and $\mathrm{N}_{2}$-fixing abilities, field studies were conducted twice at both locations with Bacillus pumilus and reduced application of $\mathrm{N}$ and P fertilizers (Kaushal and Kaushal, 2015). The treatments: T1 (Uninoculated control), T2 (Bacillus pumilus $+25 \%$ NP), T3 (Bacillus pumilus $+50 \%$ NP), T4 (Bacillus pumilus $+75 \%$ NP), T5 (Bacillus pumilus $+100 \%$ NP), T6 (100\% NPK), T7 (75\% NPK), T8 (50\% NP), T9 (Bacillus pumilus-inoculation) and T10 (Recommended dose of fertilizers) were arranged in randomized complete block design (RCBD) and replicated thrice. Calcium ammonium nitrate $(25 \% \mathrm{~N})$ and single super phosphate $(16 \%$ $\mathrm{P}_{2} \mathrm{O}_{5}$ ) were the sources of nitrogen and phosphorus, respectively. Bacterial cell suspension (at OD $540 \mathrm{~nm} \mathrm{1.00)} \mathrm{of} 72 \mathrm{~h}$ old cultures, grown in $10 \%$ nutrient broth, was used as inoculum. Data were collected on the growth and yield parameters of cauliflower, soil nutrient status and rhizospheric as well as endophytic microbial population and analysed over recommended dose of fertilizers. We used 20 plants/treated plot for analysing the data and each plant is harvested manually and recorded for growth and yield parameters which includes number of non-wrapper leaves, curd diameter and curd weight.

\section{Efficacy of Bacillus pumilus inoculation on soil microbial biomass and microbial activity (CO2 evolution)}

We analysed the incremental growth of microbial biomass-carbon and microbial activity $\left(\mathrm{CO}_{2}\right.$ evolution) over time. The fumigation-extraction method was used to analyse soil microbial biomass-C (CMIC) (Vance et al., 1987). Microbial activity was measured as the $\mathrm{CO}_{2}$ evolved from moist soil, adjusted to $55 \%$ water holding capacity, and pre-incubated for 7 days at $20{ }^{\circ} \mathrm{C}$ in the dark. The $\mathrm{CO}_{2}$ evolution was then measured 
for the next 7 days using $\mathrm{NaOH}$ traps and titration with $\mathrm{HCl}$ and the metabolic quotient $\left(\mathrm{qCO}_{2}\right)$ was calculated (Salamanca et al., 2002).

\section{Statistical analysis}

All samples were measured in triplicate. The selected variables were compared between the tested soils using a one-way ANOVA. Significant differences were detected at the 0.05 level. Correlations between all measurable variables (plant, soil and microbial) were estimated using Pearson's $\mathrm{r}$ with $\mathrm{p}<0.05$ significance threshold. Principal components analysis (PCA) was conducted to determine and clarify the relationship between plant, soil and microbial parameters.

\section{Results and discussion}

\section{Plant growth promoting rhizobacterial traits of Bacillus pumilus}

Bacillus pumilus was the native bacterial strain isolated from rhizosphere of cauliflower. Our earlier published results confirmed that this strain displayed a very high ability towards most of the plant growth promoting attributes (Kaushal et al., 2017).

The isolate (Bacillus pumilus) produced a significantly higher concentration Psolubilization $(664.33 \mu \mathrm{g} / \mathrm{mL})$, IAA $(29.67 \mu \mathrm{g} / \mathrm{mL})$, maximum $(51.36 \%)$ siderophore unit and HCN production (Fig. 2).

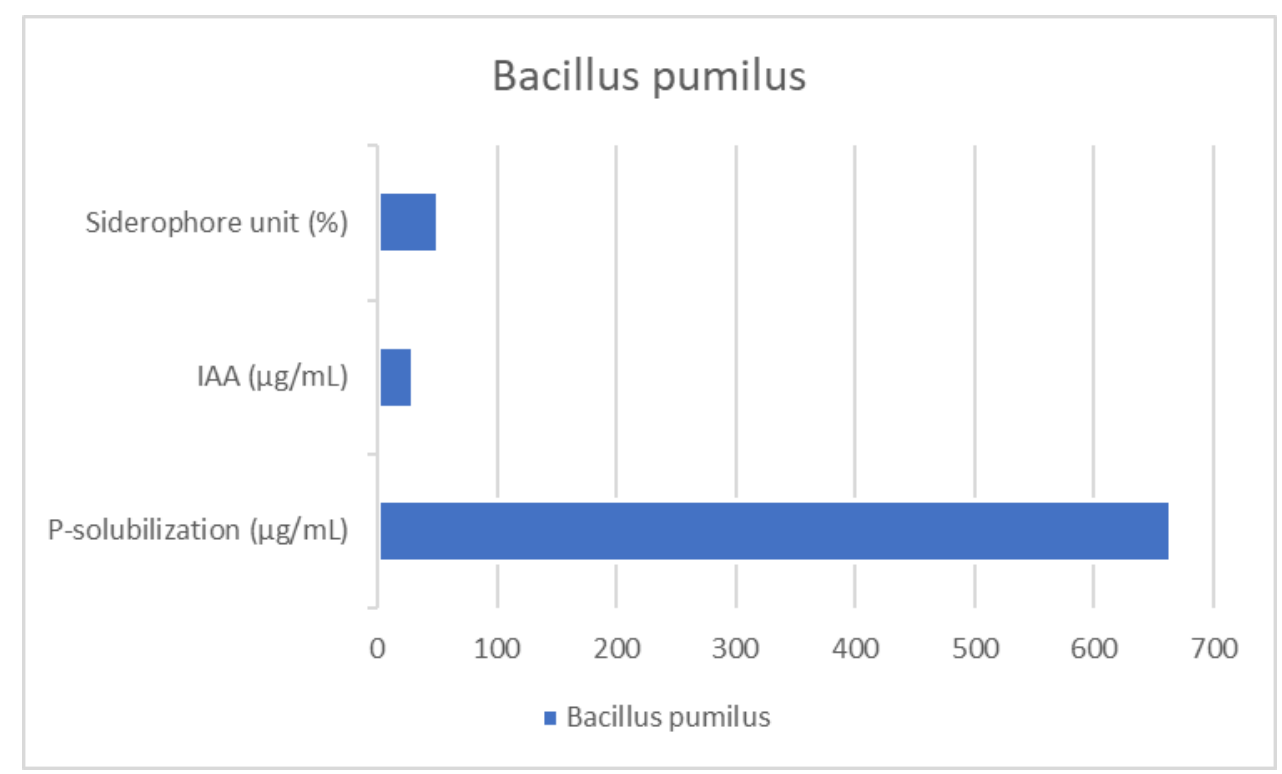

Figure 2. Plant growth promoting activities of selected bacterial isolates (Bacillus pumilus). *Significance $<0.05$

Inorganic phosphate is solubilized by rhizosphere microbes with the production of organic acids and chelating oxo-acids from sugar (Cao et al., 2017). Thus, most quantitative analysis to evaluate the efficacy of phosphate-solubilizing bacteria due to the production of organic acids into surrounding medium are based on lowering $\mathrm{pH}$ (Bini et al., 2011). IAA produced by B. pumilus can enhance plant growth which was 
the same as synthetic PGRs produced (Dasri et al., 2016). Siderophore and HCN production was also exhibited by Bacillus pumilus used as potential biocontrol agent of Fusarium in tomato (Heidarzadeh and Baghaee-Ravari, 2016). With regards to antagonistic activity against Sclerotinia sclerotiorum, culture filtrate of Bacillus pumilus exhibited very high antifungal antibiotic activity with an inhibition zone ranged from 20.2 to $22.4 \mathrm{~mm}$. Our results are agreement with other researchers., who demonstrated that Bacillus pumilus strain is a promising biological control agent for control against Sclerotinia stem rot (Gao et al., 2014). Bacillus pumilus also showed higher nitrogenase activity, i.e., $437.26 \eta$ mole $\mathrm{C}_{2} \mathrm{H}_{4} \mathrm{~h}^{-1} \mathrm{mg}^{-1}$ protein $\left(109 \mathrm{mg}\right.$ of $\mathrm{N}_{2}$ fixed/ha/d), as compared to standard of Azotobacter chroococcum, i.e., $372.85 \eta$ mole $\mathrm{C}_{2} \mathrm{H}_{4} \mathrm{~h}^{-1} \mathrm{mg}^{-1}$ protein (93.0 mg of $\mathrm{N}_{2}$ fixed/ha/d). In support to our results, a representative strain of Bacillus pumilus was identified that is also able to fix atmospheric $\mathrm{N}_{2}$ as determined by the acetylene-dependent production assay (Castellano-Hinojosa et al., 2016).

\section{Field efficacy of Bacillus pumilus inoculation}

Our earlier published results confirmed that bio-inoculation of Bacillus pumilus at $75 \%$ of $\mathrm{N}$ and $\mathrm{P}$ fertilizers significantly enhanced all the growth and yield parameters of cauliflower such as number of non-wrapper leaves, curd weight and curd diameter (Kaushal and Kaushal, 2015).

Field experiment data of two years for both locations (replicated twice) revealed that bio inoculation of Bacillus pumilus along with $75 \%$ NP increased curd yield by $27.65 \%$ over recommended dose of fertilizers along with the saving of $25 \%$ NP (Fig. 3). Application of beneficial microbes to crop plants enhanced the fixation of atmospheric $\mathrm{N}$, organic decomposition and augmented the soil properties by production of bioactive compounds such as vitamins, phytohormones which accelerated plant growth and yield (Upadhyay et al., 2012). The increase in levels of chemical fertilizers (NP) along with the bio-inoculation of Bacillus pumilus significantly enhanced NPK content in plants. Two years data (each replicated twice) revealed that $\mathrm{N}$ contents increased by $4.46 \%$ and $3.29 \%, \mathrm{P}$ contents $0.49 \%$ and $0.57 \%$, K contents $3.84 \%$ and $3.02 \%$ over uninoculated controls at Kullu and Solan, respectively. Uptake of N $(77.14 \mathrm{~kg} / \mathrm{ha}$ and $90.86 \mathrm{~kg} / \mathrm{ha})$ and $\mathrm{P}(35.28 \mathrm{~kg} / \mathrm{ha}$ and $26.22 \mathrm{~kg} / \mathrm{ha})$ also boosted significantly with progressive increase in the supply of $\mathrm{N}$ and $\mathrm{P}$ nutrients along with bio-inoculation of Bacillus pumilus to the crop in both the years and locations. As far as ameliorations in plants nutrient status is concerned, enhanced nutrients like $\mathrm{N}, \mathrm{P}$ and $\mathrm{K}$ might be due to enhanced vegetative growth and improved soil health leading to increased root formation. Studies reported enhanced N, P and K constituent of plant which might be attributed to presence of abundant number of soil microorganisms, microbial respiration and microbial biomass $\mathrm{C}$ and align with the findings of other researchers (Liu et al., 2012; Santibanez and Varnero, 2014). In addition, increased level of P might be due to presence of adequate organic acids which were released after organic matter decomposition and subsequently help in the solubilization of the indigenous phosphates. It was interesting to note that larger the total rhizosphere population, more is the accumulation of nitrogen, phosphorus and potassium contents in plants. Soil physicochemical and nutrient status, i.e. $\mathrm{pH}$, electrical conductivity (EC), bulk density (BD), organic matter $(\mathrm{OM}), \mathrm{N}, \mathrm{P}, \mathrm{K}$, was also assessed after harvest of crop (Fig. 3). Concentration of nutrients increased in soil with the combined use of Bacillus pumilus and NP fertilizers. The available nutrient contents $\mathrm{N}$ and $\mathrm{P}$ were increased by $2.56-$ $32.00 \%$ and $6.66-40.72 \%$, respectively over control. Bio-inoculation of Bacillus 
pumilus not only improved the nutritional content particularly NPK of plants but also increased their uptake significantly over uninoculated control. This increase may be attributed to atmospheric nitrogen fixation, phosphate solubilization in the rhizosphere by Bacillus pumilus. The higher concentration of soil available nutrients with conjoint use of Bacillus pumilus and NP fertilizers may be attributed to well develop root system, significant improvement in soil physical properties and metabolic activity as well as rhizospheric and endophytic microbial population (Kaushal and Wani, 2016). The microbial analysis performed at the harvest of crop in each year at both the locations. The data revealed higher population of rhizospheric and endophytic bacteria in duly inoculated plots as compare to uninoculated control. The highest $162.5 \times$ $10^{8} \mathrm{cfu} / \mathrm{g}$ soil and $158.8 \times 10^{8} \mathrm{cfu} / \mathrm{g}$ soil rhizospheric population was recorded at Kullu and Solan, respectively. The lowest total bacterial counts were recorded under uninoculated control at both the locations. Also, endophytic bacterial population was highest $106.4 \times 10^{1} \mathrm{cfu} / \mathrm{g}$ root (Kullu) and $108.8 \times 10^{1} \mathrm{cfu} / \mathrm{g}$ root (Solan). At both the locations, the lowest endophytic bacterial counts were recorded with uninoculated control. The rhizosphere is a niche of beneficial microflora. Higher root exudation, OC, $\mathrm{N}$ and moisture content in amended organic fertilizers mechanized the microbes for their proliferation (Nagar et al., 2016). Decomposition of root tissue contribute ample energy in terms of $\mathrm{C}$ and $\mathrm{N}$ for the multiplication of bacteria enabling the growth of heavy microbial population (Singh et al., 2012). Moreover, increase in beneficial microbial population may be because of balanced water supply, particulate organic matter and presence of respirable substances (Majumdar et al., 2014). The study revealed that bio-inoculation of Bacillus pumilus supplied plots improved the cauliflower yield, physico-chemical properties of soil leading to enhanced soil microbiome (Fig. 3).

\section{Efficacy of Bacillus pumilus inoculation on soil microbial biomass and microbial activity (CO2 evolution)}

Soil microbial biomass-carbon (SMBC) was significantly higher in Bacillus pumilus $+75 \%$ NP plots (Figs. 4 and 5). This might be due to enhanced mineralization of organic leading to increased microbial activity (Nagar et al., 2016) as revealed in our studies also. SMBC at Kullu was $119.8 \mathrm{mg} \mathrm{MB-C/} 100 \mathrm{~g}$ soil and Solan was $117.6 \mathrm{mg}$ MB-C/ $100 \mathrm{~g}$ soil both with bio-inoculation of Bacillus pumilus $+75 \%$ of $\mathrm{N}$ and $\mathrm{P}$ fertilizers as presented in Figures 4 and 5. Similarly, various studies displayed that increased population of Azotobacter, PSB, soil enzymes, OC exhibited positive correlation with SMBC (Majumdar et al., 2014). Moreover, significiant improvement in SMBC in our experiments might be due to more stimulation in associated microbial populations. Treatments consisting of Bacillus pumilus bio-inoculation and chemical fertilizers (NP) increased the $\mathrm{CO}_{2}$ evolution up to $48 \mathrm{~h}$ of incubation period and then followed a decreasing trend with the increase in incubation period at both the locations. However, the maximum $\mathrm{CO}_{2}$-evolution was recorded $0.18 \mathrm{mg} \mathrm{CO}_{2} / \mathrm{g}$ soil (Kullu) and $0.17 \mathrm{mg} \mathrm{CO}_{2} / \mathrm{g}$ soil (Solan) with bio-inoculation of Bacillus pumilus $+75 \%$ of $\mathrm{N}$ and $\mathrm{P}$ fertilizers as presented in Figures 6 and 7. The basal soil respiration gives an estimate of total microbial activity, reflecting both the quantity and quality of the carbon sources (Liu et al., 2012). In present study, higher soil respiration sustained our notion that the rhizosphere soils had a dominant soil microbial activity, implying accelerated decomposition of organic residues that makes nutrients available for the consequent stimulation of heterotrophic microorganisms as observed by other researchers (Fall et 
al., 2012). Moreover, the lower soil microbial metabolic quotient $\left(\mathrm{qCO}_{2}\right)$ displayed lower soil chemical stress to microbes, more worthwhile $\mathrm{C}$ utilization ability, low energy demand in microbial biomass supply and improved soil quality (GonzalezQuinones et al., 2011). Our results also suggested that inorganic fertilization did not increase soil respiration. Similar effects on soil respiration due to inorganic fertilization has been found when $\mathrm{N}$ fertilizer was added, possibly from the elimination of the decomposition of soil organic carbon due to reduction in microbial biomass (Yang et al., 2010; Ge et al., 2012).

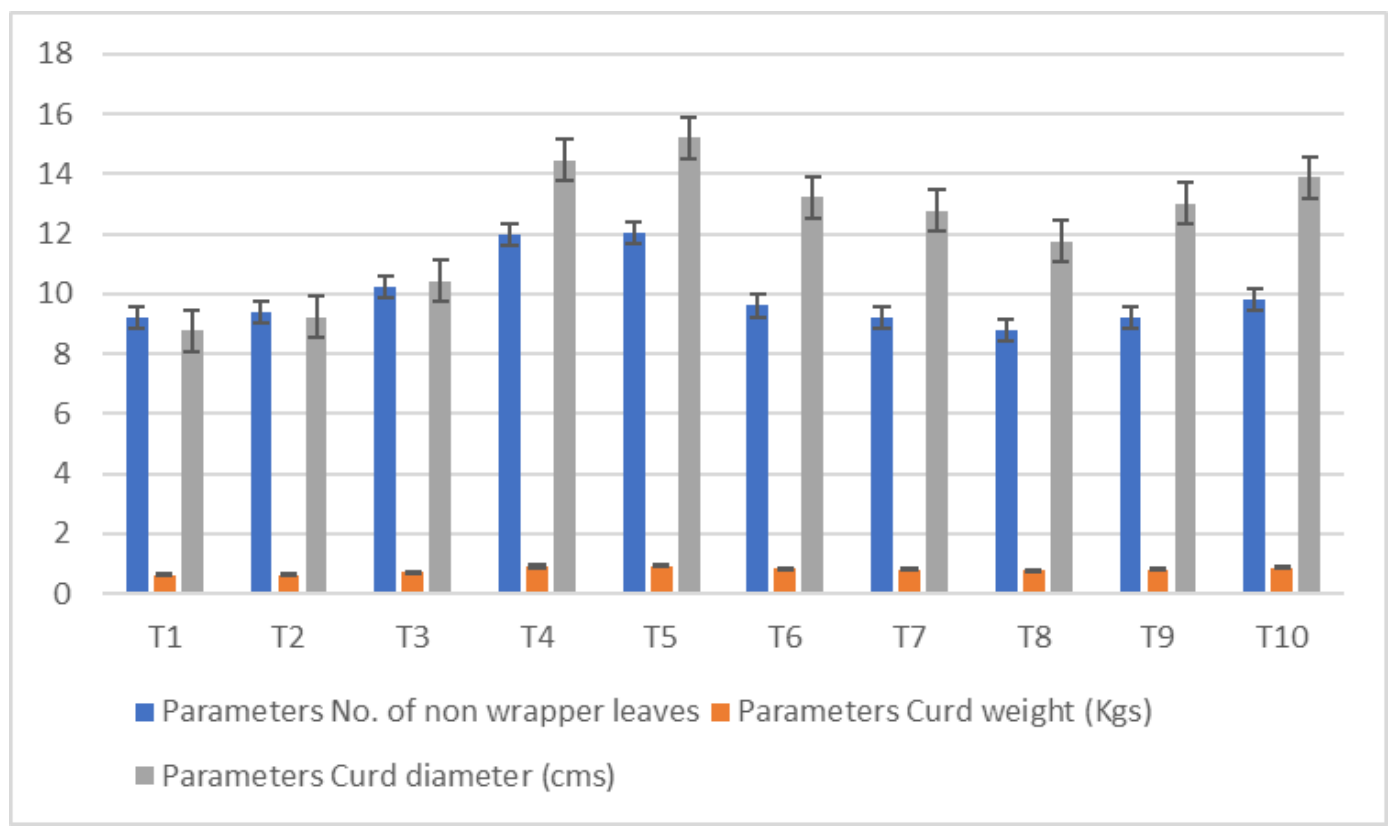

a

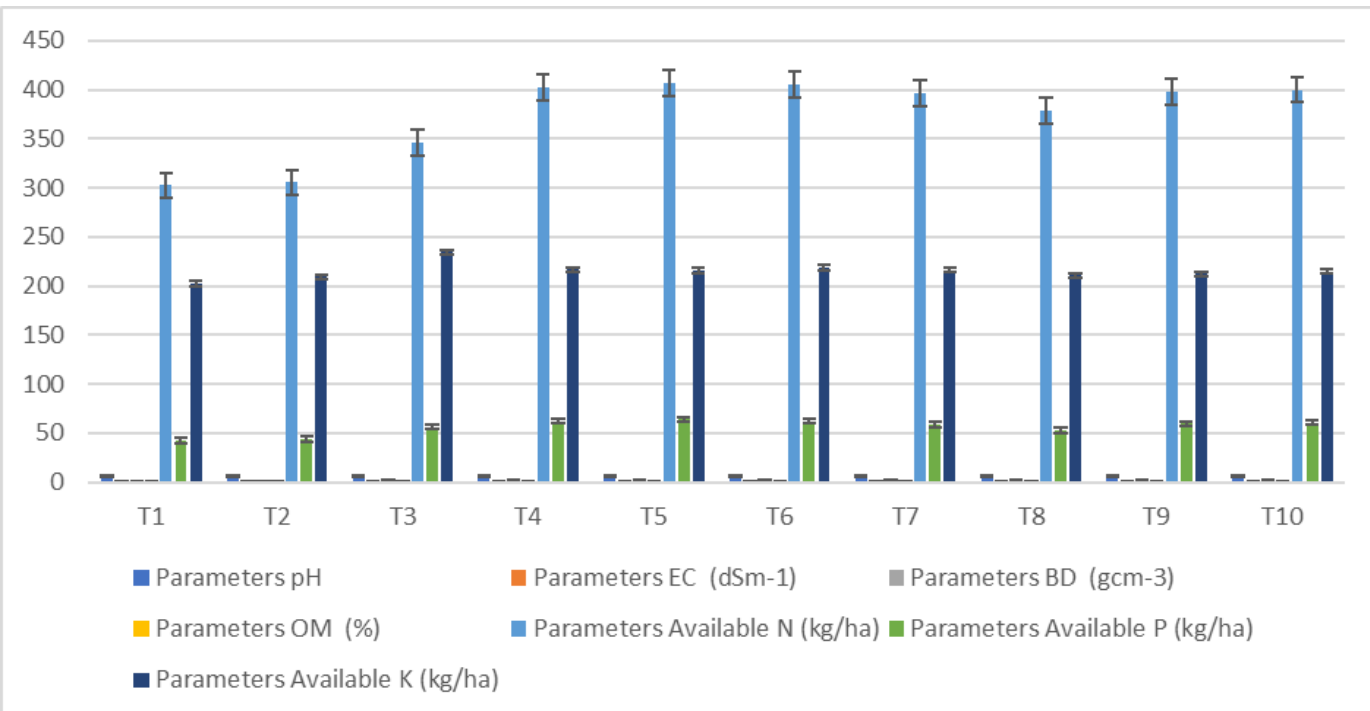

b

Figure 3. Impact of selected bacterial isolates (Bacillus pumilus) on (a) plant and (b) soil parameters. T1 (uninoculated control), T2 (Bacillus pumilus $+25 \% \mathrm{NP}$ ), T3 (Bacillus pumilus $+50 \%$ NP), 74 (Bacillus pumilus $+75 \%$ NP), T5 (Bacillus pumilus $+100 \%$ NP), T6 $(100 \%$ NPK), T7 (75\% NPK), T8 (50\% NP), T9 (Bacillus pumilus-inoculation) and T10 (recommended dose of fertilizers) *Significance $<0.05$ 


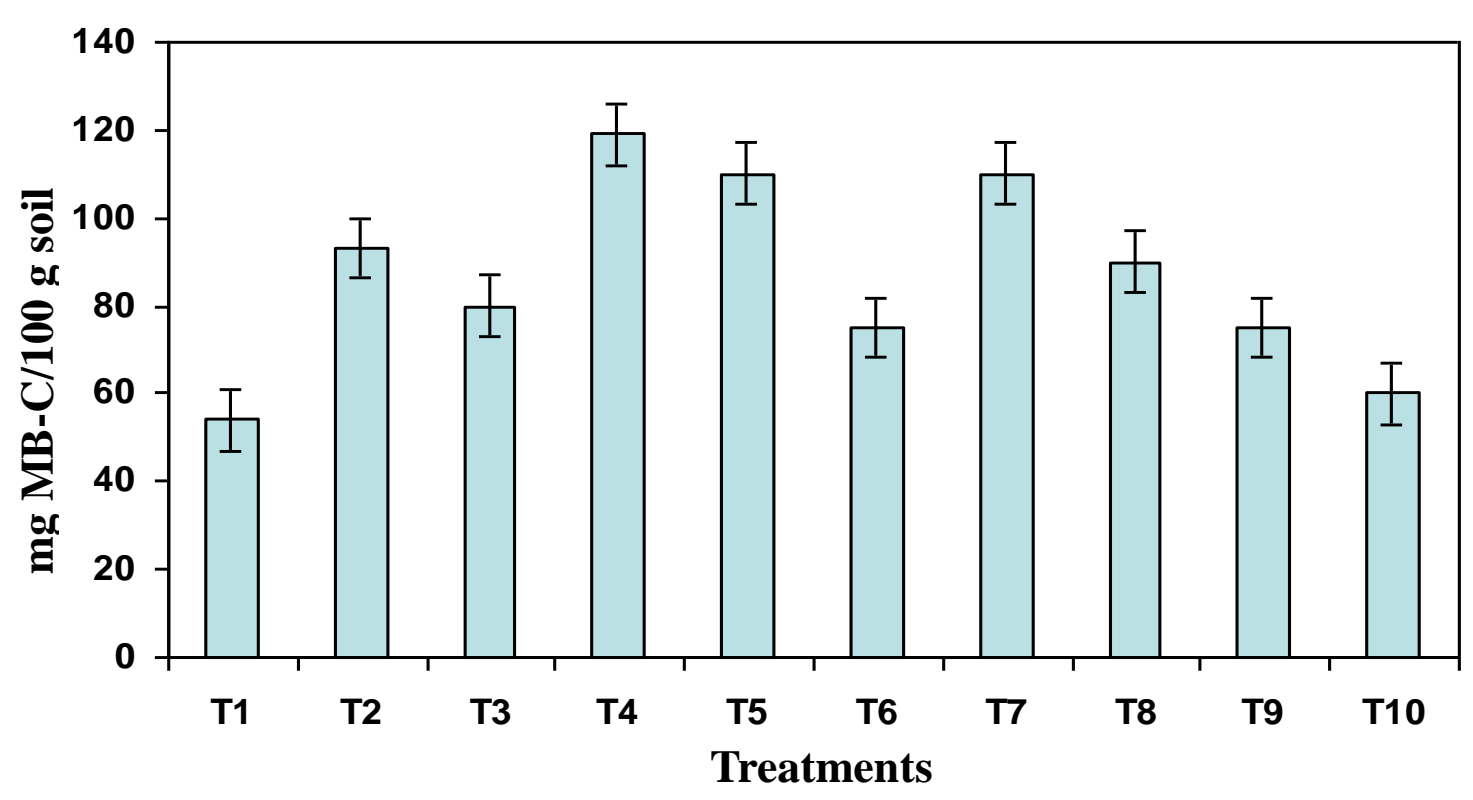

Figure 4. Impact of bio-inoculation of Bacillus pumilus on microbial biomass-carbon at Solan. T1 (uninoculated control), T2 (Bacillus pumilus $+25 \% \mathrm{NP}$ ), T3 (Bacillus pumilus $+50 \% \mathrm{NP}$ ), T4 (Bacillus pumilus + 75\% NP), T5 (Bacillus pumilus $+100 \%$ NP), T6 (100\% NPK), T7 (75\% NPK), T8 (50\% NP), T9 (Bacillus pumilus-inoculation) and T10 (recommended dose of fertilizers). *Significance $<0.05$

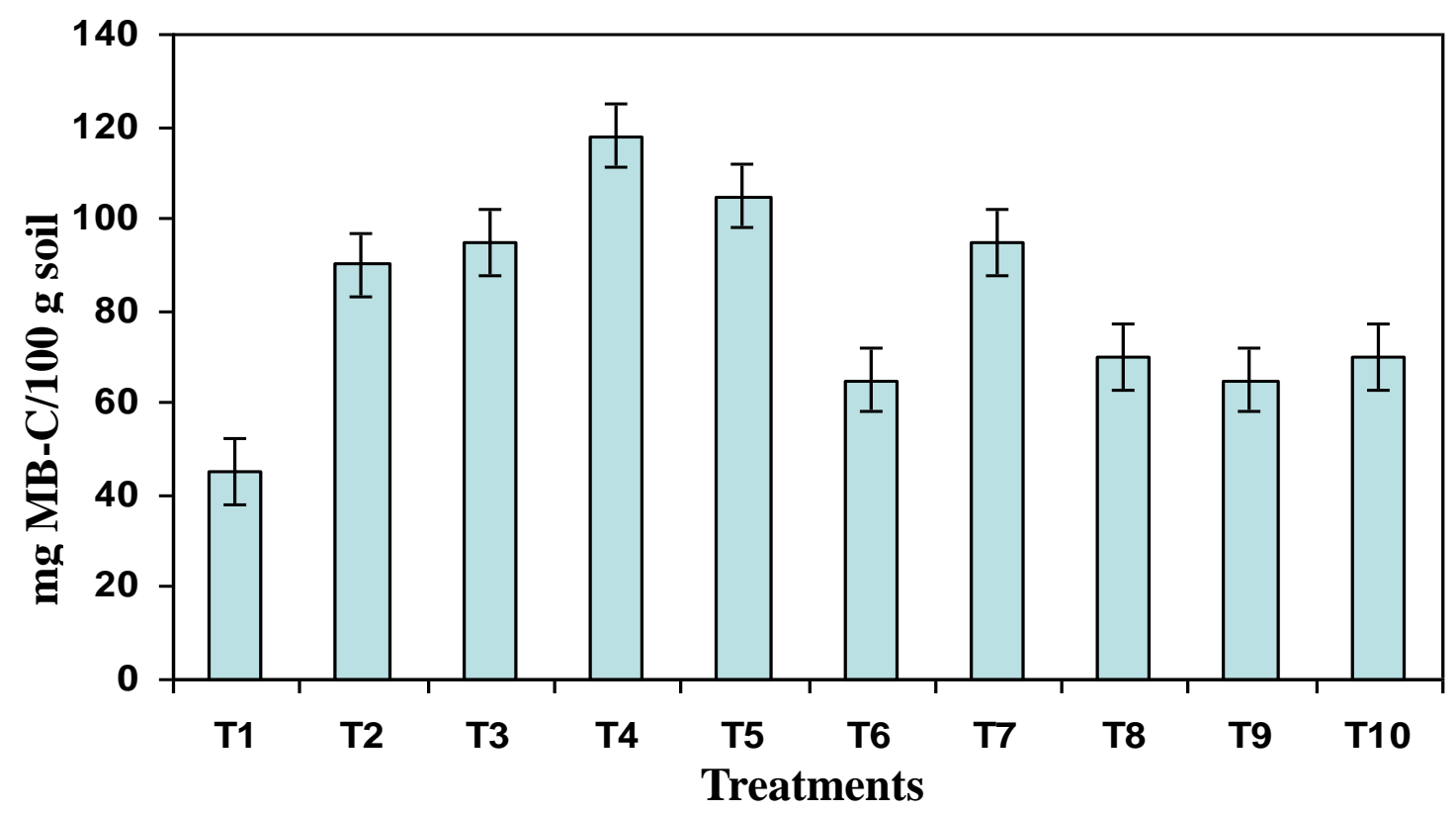

Figure 5. Impact of bio-inoculation of Bacillus pumilus on microbial biomass-carbon at Solan. T1 (uninoculated control), T2 (Bacillus pumilus $+25 \% \mathrm{NP}$ ), T3 (Bacillus pumilus $+50 \% \mathrm{NP}$ ), T4 (Bacillus pumilus + 75\% NP), T5 (Bacillus pumilus + 100\% NP), T6 (100\% NPK), T7 (75\% NPK), T8 (50\% NP), T9 (Bacillus pumilus-inoculation) and T10 (recommended dose of fertilizers). *Significance $<0.05$ 

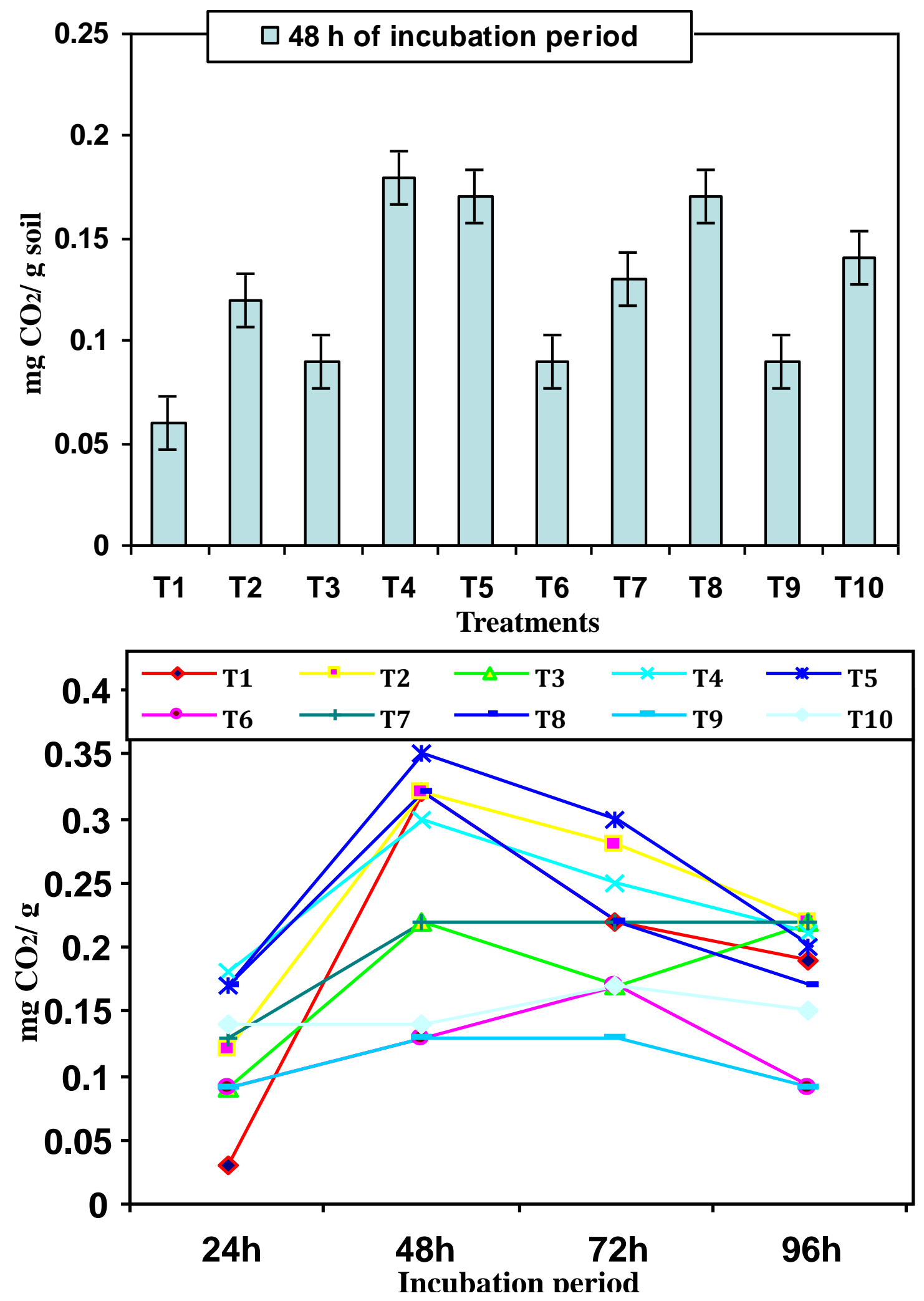

Figure 6. Impact of bio-inoculation of Bacillus pumilus on microbial activity ( $\mathrm{CO}_{2}$ evolution) at Kullu. T1 (uninoculated control), T2 (Bacillus pumilus $+25 \%$ NP), T3 (Bacillus pumilus $+50 \%$ NP), T4 (Bacillus pumilus + 75\% NP), T5 (Bacillus pumilus + 100\% NP), T6 (100\% NPK), T7 (75\% NPK), T8 (50\% NP), T9 (Bacillus pumilus-inoculation) and T10 (recommended dose of fertilizers). *Significance $<0.05$ 

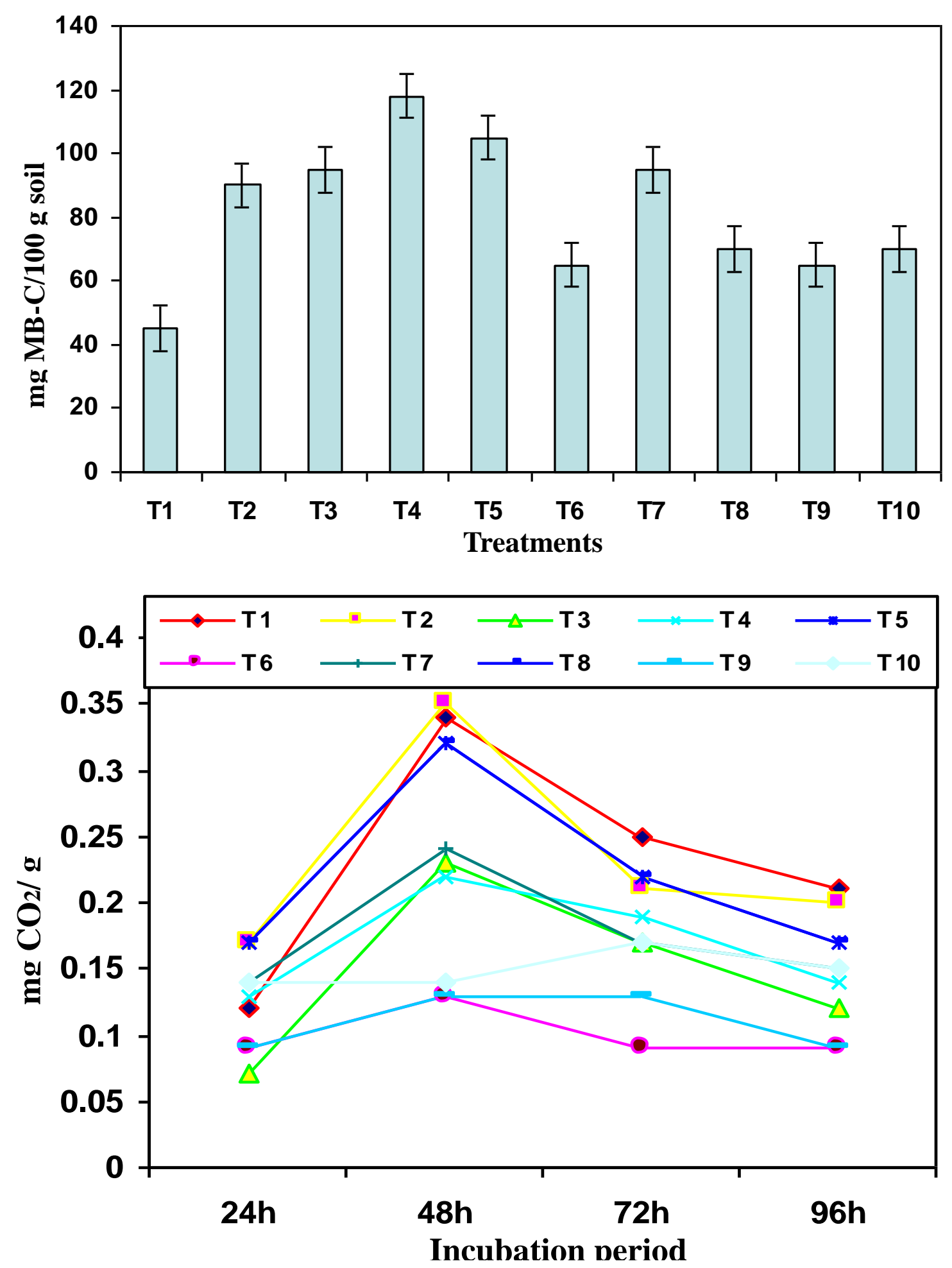

Figure 7. Impact of bio-inoculation of Bacillus pumilus on microbial activity ( $\mathrm{CO}_{2}$ evolution) at Kullu. T1 (uninoculated control), T2 (Bacillus pumilus $+25 \%$ NP), T3 (Bacillus pumilus $+50 \%$ NP), T4 (Bacillus pumilus + 75\% NP), T5 (Bacillus pumilus + 100\% NP), T6 (100\% NPK), T7 (75\% NPK), T8 (50\% NP), T9 (Bacillus pumilus-inoculation) and T10 (recommended dose of fertilizers). *Significance $<0.05$ 


\section{Correlations analysis}

Pearson correlation matrix revealed that many plant, soil and microbial variables were significantly correlated with each other The plant parameters, i.e. number of nonwrapper leaves, curd diameter, curd weight, curd yield, curd depth, soil physicochemical, i.e. $\mathrm{pH}, \mathrm{EC}, \mathrm{BD}, \mathrm{OM}, \mathrm{N}, \mathrm{P}, \mathrm{K}$, rhizospheric and endophytic bacterial population was significantly correlated at $5 \%$ level of significance at Kullu as given in Table 2. Significant positive correlation exists between curd diameter-N, $\mathrm{P}(\mathrm{r}=0.49$, 0.48 respectively), curd diameter-rhizospheric bacterial population $(\mathrm{r}=0.42)$, curd diameter-endophytic bacterial population $(\mathrm{r}=0.38)$, curd weight- $\mathrm{N}, \mathrm{P}(\mathrm{r}=0.65,0.73$, respectively), curd weight-rhizospheric bacterial population $(\mathrm{r}=0.35)$, curd weightendophytic bacterial population $(\mathrm{r}=0.50)$, curd yield-N, $\mathrm{P}(\mathrm{r}=0.65,0.73$ respectively), curd yield-rhizospheric bacterial population $(\mathrm{r}=0.35)$ curd yield-endophytic bacterial population $(\mathrm{r}=0.50)$, curd depth-N, $\mathrm{P}(\mathrm{r}=0.50,0.51$ respectively), curd depthrhizospheric bacterial population $(\mathrm{r}=0.32)$, curd depth-endophytic bacterial population $(\mathrm{r}=0.33)$, N-rhizospheric bacterial population $(\mathrm{r}=0.42)$, P-rhizospheric bacterial population $(r=0.43)$, P-endophytic bacterial population $(r=0.32)$ and between $\mathrm{K}$ endophytic bacterial population $(\mathrm{r}=0.53)$. The plant parameters, i.e. number of nonwrapper leaves, curd diameter, curd weight, curd yield, curd depth, soil physicochemical, i.e. $\mathrm{pH}, \mathrm{EC}, \mathrm{BD}, \mathrm{OM}, \mathrm{N}, \mathrm{P}, \mathrm{K}$, rhizospheric and endophytic bacterial population was significantly correlated at $5 \%$ level of significance at at Solan as given in Table 3. Significant positive correlation exists between number of non-wrapper leaves-N, $\mathrm{P}(\mathrm{r}=0.32,0.52$ respectively), number of non-wrapper leaves-rhizospheric bacterial population $(\mathrm{r}=0.41)$, curd diameter- $\mathrm{N}, \mathrm{P}(\mathrm{r}=0.47,0.59$ respectively), curd diameter-rhizospheric bacterial population $(\mathrm{r}=0.46)$, curd diameter-endophytic bacterial population $(\mathrm{r}=0.35)$, curd weight- $\mathrm{N}, \mathrm{P}(\mathrm{r}=0.76,0.84$ respectively), curd weight-rhizospheric bacterial population $(\mathrm{r}=0.38)$, curd yield- $\mathrm{N}, \mathrm{P}(\mathrm{r}=0.76,0.84$, respectively), curd yield-rhizospheric bacterial population $(\mathrm{r}=0.38)$, curd depth-N, $\mathrm{P}$ $(\mathrm{r}=0.52,0.68$, respectively), curd depth-rhizospheric bacterial population $(\mathrm{r}=0.37), \mathrm{P}-$ rhizospheric bacterial population $(\mathrm{r}=0.47)$ and between $\mathrm{P}$-endophytic bacterial population $(\mathrm{r}=0.31)$. In our results, positive correlation between plant, soil and bacterial variables was obtained which showed a considerably positive relationship. Enhanced SMBC might be one of the determinant factor of this positive relationship. Moreover, as predicted in our findings, $\mathrm{MBC}$ is the important source of $\mathrm{C}$ supplying higher energy to the microbes leading to enhanced metabolic activities (Liu et al., 2017). The rhizosphere microbial community is recognized to be closely related to soil health and quality (Raaijmakers and Mazzola, 2016). The positive correlation between $\mathrm{N}$-rhizospheric bacterial population $(\mathrm{r}=0.42)$, P-rhizospheric bacterial population $(\mathrm{r}=0.43)$, P-endophytic bacterial population $(\mathrm{r}=0.32)$ and between K-endophytic bacterial population $(\mathrm{r}=0.53)$ revealed in the field experiments corresponds with many previous studies, suggesting that the soil quality is directly related to bacterial population occurrence and could therefore be used as an indicator for soil fertility prediction. Moreover, bio-inoculation of Bacillus pumilus significantly induce the community shift of culturable bacteria in the rhizosphere soil leading to improved soil microbial biomass. From a long-term perspective, appropriate application of Bacillus pumilus can improve the soil quality and fertility. This comprises both nutrients (e.g., aggregation of organic matter) and structure (e.g., aggregates accumulation), which is conductive to agricultural sustainable development. The results also suggested a positive effect of $\mathrm{N}$ application on microbial biomass-C. After $\mathrm{N}$ application, $\mathrm{N}$ 
availability increased and consequently microbes immobilized $\mathrm{N}$, which subsequently increased microbial biomass-C (Chaparro et al., 2014). A clear positive effect of combined application of Bacillus pumilus and NP on microbial biomass and microbial activity was observed. Microbial activity also varies considerably among the treatments including control. The metabolic quotient (soil respiration per unit of microbial biomass) reflects the maintenance energy requirement of soil microbes and can be a relative measure of how efficiently the soil microbial biomass is utilizing $\mathrm{C}$ resources, as well as the degree of substrate limitation for soil microbes (Xun et al., 2016). The results in this study did show changes in the microbial pool that would suggest changes in microbial biomass-C and activity as well (Tables 2 and 3). In contrast, combined application of Bacillus pumilus and NP treatments indicated relatively highly efficient microbial community and better use of the available organic substrates. On the contrary, the Pearson's correlation indicated strongly positive correlation between microbial biomass and plant and soil parameters (Tables 2 and 3). All the soil factors controlling microbial biomass- $\mathrm{C}$ had significant effects on microbial respiration $\left(\mathrm{CO}_{2}\right.$ evolution) as described by the correlation analysis.

Principal components analysis was used to determine the factors related to soil microbial properties. The two components (PC1 and PC2) explained $63.54 \%$ and $12.82 \%$ of the total variance. The PC1 and PC2 were chosen to draw a biplot, because of explaining $76.36 \%$ of the total variance together as presented in Figure 8. PCA was weighted by physico-chemical ( $\mathrm{pH}, \mathrm{EC}, \mathrm{BD}, \mathrm{OM}, \mathrm{N}, \mathrm{P}$ and $\mathrm{K}$ ), which exhibited a more powerful influence on discrimination in soil samples and microbiological (rhizospheric and endophytic bacterial population) variables together with growth and yield components. Thus, PCA allowed us to detect the subtle differences in plant, soil physical-chemical and microbial factors among the studied parameters. Additionally, the high soil organic matter (SOM) and $\mathrm{N}$ contents as material basis largely contribute to the high microbial biomass and basal respiration. Also, changes in SOM and $\mathrm{N}$ application affects soil microbial biomass $(\mathrm{SOM} / \mathrm{N} \propto \mathrm{SMBC})$. As far as soil quality is concerned, microbial diversity should be well considered when vast of $\mathrm{N}$ fertilizer was added to soils in agricultural practice.

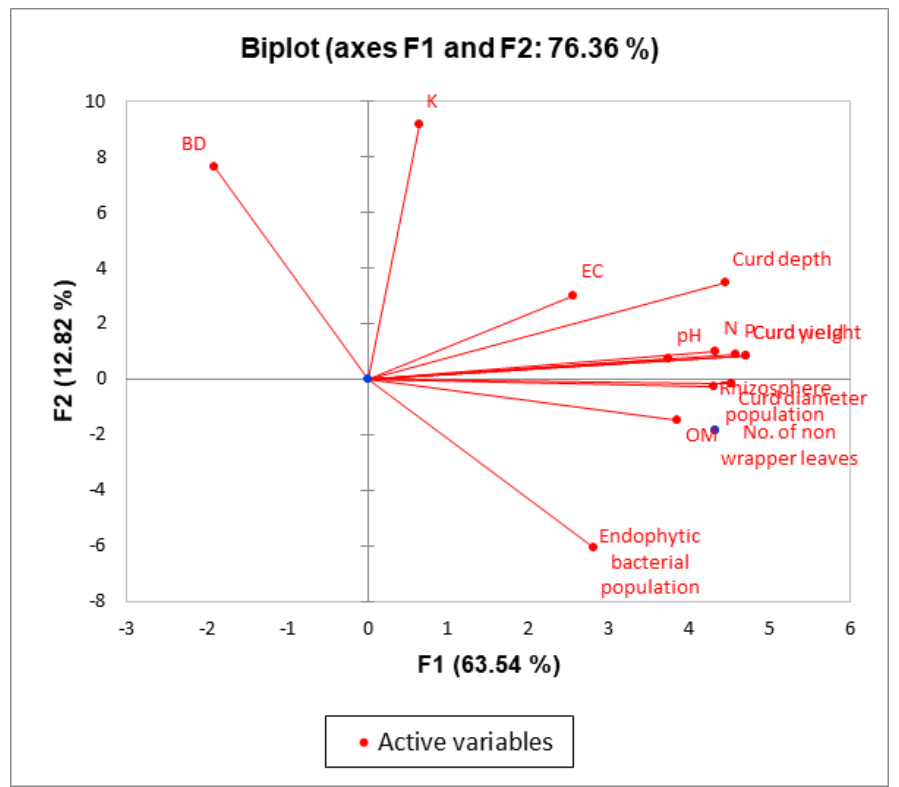

Figure 8. PCA-ordination biplot of plant, soil and microbial parameters 
Table 2. Pearson's correlation coefficient ( $r$ value) between plant, soil parameters, rhizospheric and endophytic population under field conditions experiment at Kullu $(n=30)$

\begin{tabular}{|c|c|c|c|c|c|c|c|c|c|c|c|c|c|c|}
\hline Parameters & \begin{tabular}{|c|} 
No. non \\
wrapper \\
leaves
\end{tabular} & $\begin{array}{c}\text { Curd } \\
\text { diameter }\end{array}$ & $\begin{array}{c}\text { Curd } \\
\text { weight }\end{array}$ & $\begin{array}{l}\text { Curd } \\
\text { yield }\end{array}$ & $\begin{array}{l}\text { Curd } \\
\text { depth }\end{array}$ & pH & $\begin{array}{c}\text { Electrical } \\
\text { conductivity } \\
\text { (EC) }\end{array}$ & $\begin{array}{c}\text { Bulk } \\
\text { density } \\
\text { (BD) }\end{array}$ & $\begin{array}{c}\text { Organic } \\
\text { matter } \\
(\mathrm{OM})\end{array}$ & $\begin{array}{l}\text { Nitrogen } \\
\text { (N) }\end{array}$ & $\begin{array}{c}\text { Phosphorus } \\
\text { (P) }\end{array}$ & $\begin{array}{c}\text { Potassium } \\
(\mathbf{K})\end{array}$ & $\begin{array}{c}\text { Rhizospheric } \\
\text { bacterial } \\
\text { population }\end{array}$ & $\begin{array}{c}\text { Endophytic } \\
\text { bacterial } \\
\text { population }\end{array}$ \\
\hline $\begin{array}{c}\text { No. non } \\
\text { wrapper leaves }\end{array}$ & 1.00 & & & & & & & & & & & & & \\
\hline Curd diameter & $0.49 *$ & 1.00 & & & & & & & & & & & & \\
\hline Curd weight & 0.28 & $0.64 *$ & 1.00 & & & & & & & & & & & \\
\hline Curd yield & 0.28 & $0.64 *$ & 1.00 & 1.00 & & & & & & & & & & \\
\hline Curd depth & 0.21 & $0.68^{*}$ & $0.61 *$ & $0.61 *$ & 1.00 & & & & & & & & & \\
\hline $\mathrm{pH}$ & 0.11 & -0.04 & -0.01 & -0.01 & 0.005 & 1.00 & & & & & & & & \\
\hline $\begin{array}{c}\text { Electrical } \\
\text { conductivity } \\
(\mathrm{EC})\end{array}$ & 0.15 & -0.03 & -0.02 & -0.02 & -0.18 & 0.14 & 1.00 & & & & & & & \\
\hline $\begin{array}{l}\text { Bulk density } \\
\text { (BD) }\end{array}$ & -0.12 & -0.04 & 0.07 & 0.07 & -0.002 & -0.15 & -0.01 & 1.00 & & & & & & \\
\hline Nitrogen $(\mathrm{N})$ & 0.09 & $0.49 *$ & $0.65 *$ & $0.65^{*}$ & $0.50 *$ & 0.13 & -0.05 & 0.09 & $0.35^{*}$ & 1.00 & & & & \\
\hline Phosphorus (P) & 0.17 & $0.48 *$ & $0.73^{*}$ & $0.73 *$ & $0.51 *$ & 0.14 & -0.007 & 0.16 & $0.30 *$ & $0.88 *$ & 1.00 & & & \\
\hline Potassium (K) & -0.10 & -0.10 & -0.13 & -0.13 & -0.07 & 0.02 & 0.12 & -0.03 & -0.05 & -0.17 & 0.07 & 1.00 & & \\
\hline $\begin{array}{c}\text { Rhizospheric } \\
\text { bacterial } \\
\text { population }\end{array}$ & 0.17 & $0.42 *$ & $0.35^{*}$ & $0.35 *$ & $0.32 *$ & 0.13 & 0.16 & -0.13 & 0.12 & $0.42 *$ & $0.43 *$ & 0.09 & 1.00 & \\
\hline $\begin{array}{l}\text { Endophytic } \\
\text { bacterial } \\
\text { population }\end{array}$ & 0.27 & $0.38^{*}$ & $0.50 *$ & $0.50 *$ & $0.33 *$ & -0.001 & -0.05 & -0.05 & -0.02 & 0.29 & $0.32 *$ & -0.002 & $0.53 *$ & 1.00 \\
\hline
\end{tabular}

*Significant correlation at $\alpha=.05$ level 
Table 3. Pearson's correlation coefficient ( $r$ value) between plant, soil parameters, rhizospheric and endophytic population under field conditions experiment at Solan $(n=30)$

\begin{tabular}{|c|c|c|c|c|c|c|c|c|c|c|c|c|c|c|}
\hline Parameters & $\begin{array}{c}\text { No. non } \\
\text { wrapper } \\
\text { leaves }\end{array}$ & $\begin{array}{c}\text { Curd } \\
\text { diameter }\end{array}$ & $\begin{array}{c}\text { Curd } \\
\text { weight }\end{array}$ & $\begin{array}{l}\text { Curd } \\
\text { yield }\end{array}$ & $\begin{array}{l}\text { Curd } \\
\text { depth }\end{array}$ & $\mathbf{p H}$ & $\begin{array}{c}\text { Electrical } \\
\text { conductivity } \\
\text { (EC) }\end{array}$ & \begin{tabular}{|c|} 
Bulk \\
density \\
(BD)
\end{tabular} & $\begin{array}{c}\text { Organic } \\
\text { matter } \\
(\mathrm{OM})\end{array}$ & $\begin{array}{c}\text { Nitrogen } \\
(\mathbf{N})\end{array}$ & $\begin{array}{c}\text { Phosphorus } \\
\text { (P) }\end{array}$ & $\begin{array}{c}\text { Potassium } \\
(\mathbf{K})\end{array}$ & \begin{tabular}{|c|} 
Rhizospheric \\
bacterial \\
population
\end{tabular} & $\begin{array}{c}\text { Endophytic } \\
\text { bacterial } \\
\text { population }\end{array}$ \\
\hline $\begin{array}{c}\text { No. non } \\
\text { wrapper leaves }\end{array}$ & 1.00 & & & & & & & & & & & & & \\
\hline Curd diameter & $0.35^{*}$ & 1.00 & & & & & & & & & & & & \\
\hline Curd weight & $0.45^{*}$ & $0.54 *$ & 1.00 & & & & & & & & & & & \\
\hline Curd yield & $0.45^{*}$ & $0.54 *$ & 1.00 & 1.00 & & & & & & & & & & \\
\hline Curd depth & $0.36^{*}$ & $0.40^{*}$ & $0.57 *$ & $0.57 *$ & 1.00 & & & & & & & & & \\
\hline $\mathrm{pH}$ & -0.17 & 0.26 & 0.21 & 0.21 & -0.06 & 1.00 & & & & & & & & \\
\hline $\begin{array}{c}\text { Electrical } \\
\text { conductivity } \\
(\mathrm{EC})\end{array}$ & 0.08 & 0.07 & 0.18 & 0.18 & 0.19 & 0.11 & 1.00 & & & & & & & \\
\hline $\begin{array}{l}\text { Bulk density } \\
\text { (BD) }\end{array}$ & 0.09 & -0.23 & -0.02 & -0.02 & 0.09 & -0.22 & 0.09 & 1.00 & & & & & & \\
\hline Nitrogen $(\mathrm{N})$ & $0.32 *$ & $0.47 *$ & $0.76^{*}$ & $0.76^{*}$ & $0.52 *$ & 0.22 & 0.13 & -0.19 & 0.17 & 1.00 & & & & \\
\hline Phosphorus (P) & $0.52 *$ & $0.59 *$ & $0.84 *$ & $0.84 *$ & $0.68 *$ & 0.20 & 0.14 & -0.17 & 0.26 & $0.83^{*}$ & 1.00 & & & \\
\hline Potassium (K) & 0.07 & -0.09 & 0.06 & 0.06 & -0.07 & 0.17 & 0.15 & -0.02 & 0.12 & 0.06 & 0.07 & 1.00 & & \\
\hline $\begin{array}{c}\text { Rhizospheric } \\
\text { bacterial } \\
\text { population }\end{array}$ & $0.41 *$ & $0.46^{*}$ & $0.38 *$ & $0.38 *$ & $0.37 *$ & 0.10 & 0.07 & -0.15 & 0.26 & 0.26 & $0.47 *$ & 0.05 & 1.00 & \\
\hline $\begin{array}{l}\text { Endophytic } \\
\text { bacterial } \\
\text { population }\end{array}$ & 0.22 & $0.35^{*}$ & 0.22 & 0.22 & 0.26 & -0.12 & -0.14 & -0.04 & 0.08 & 0.26 & $0.31 *$ & -0.05 & $0.42 *$ & 1.00 \\
\hline
\end{tabular}

$*$ Significant correlation at $\alpha=.05$ level 


\section{Conclusion}

The inference could be drawn that inclusion of rhizobacteria in CSA ensures win win results of enhanced sustainable productivity, resilience and reduced GHG emissions. The conjoint application of Bacillus pumilus + NP (75\%) showed higher impacts on plant productivity as well as soil fertility. Plant nutrients $(\mathrm{N}, \mathrm{P}$ and $\mathrm{K})$ and microbial population registered manifold improvement in organically sound (Bacillus pumilus + NP) plots as compared to control. SMBC was found to be higher in Bacillus pumilus + $75 \%$ NP treated plots as compared to other treatment plots. Similar trends were recorded in the bacterial (rhizospheric and endophytic) populations. A significant reduction in $\mathrm{CO}_{2}$ evolution was recorded after $48 \mathrm{~h}$ of incubation in the treatments receiving Bacillus pumilus bio-inoculation. Therefore, based on these findings it is concluded that this fertilization regime (Bacillus pumilus $+\mathrm{NP}$ ) not only could produce a good yield but also offers an opportunity for savings of fertilizers and mitigation of soil pollution. Despite the information gained from this detailed study, other relationships needed to know turnover rates of microbial biomass and microbial activity for which detail work using isotope dating is in progress.

\section{REFERENCES}

[1] Anandaraj, M., Dinesh, R. (2008): Use of Microbes for Spices Production. - In: Parthasarathy, V. A., Kandiannan, K., Srinivasan, V. (eds.) Organic Spices. New India Publishing Agency, New Delhi, pp. 101-132.

[2] Bini, Y. K., Anandaraj, M., Dinesh, R., Silna, N., Kumar, A. (2011): Evaluation of PGPR strains for growth and disease suppression in ginger (Zingiber officinale Rosc.). Proceedings of 2nd Asian PGPR Conference, Beijing, China.

[3] Cao, Y., Halane, M. K., Gassmann, W., Stacey, G. (2017): The role of plant innate immunity in the legume-Rhizobium symbiosis. - Annual Review of Plant Biology 68: 535-561.

[4] Castellano-Hinojosa, A., Correa-Galeote, D., Palau, J., Bedmar, E. J. (2016): Isolation of $\mathrm{N}_{2}$-fixing rhizobacteria from Lolium perenne and evaluating their plant growth promoting traits. - Journal of Basic Microbiology 56: 85-91.

[5] Chaparro, J. M., Badri, D. V., Vivanco, J. M. (2014): Rhizosphere microbiome assemblage is affected by plant development. - ISME Journal 8: 790-803.

[6] Dasri, K., Munglue, P., Rattana, K., Sangchanjiradet, S. (2016): The effects of IAA produced by Bacillus pumilus A1_YM_1 on growth of orchids under micropropagation. Khon Kaen Agriculture Journal 44: 832-837.

[7] Dinesh, R., Ghoshal Chaudhuri, S. (2013): Soil biochemical/microbial indices as ecological indicators of land use change in mangrove forests. - Ecological Indicators 32: 253-258.

[8] Ding, W., Yu, H., Cai, Z., Han, F., Xu, Z. (2010): Responses of soil respiration to N fertilization in a loamy soil under maize cultivation. - Geoderma 155: 381-389.

[9] Fall, D., Diouf, D., Zoubeirou, A. M., Bakhoum, N., Faye, A., Sall, S. N. (2012): Effect of distance and depth on microbial biomass and mineral nitrogen content under Acacia senegal (L.) Wild. trees. - Journal of Environment Management 95: S260-S264.

[10] Gao, X., Han, Q., Chen, Y., Qin, H., Huang, L., Kang, Z. (2014): Biological control of oilseed rape Sclerotinia stem rot by Bacillus subtilis strain Em7. - Biocontrol Science and Technology 24: 39-52. 
[11] Ge, X., Xiao, W., Zeng, L., Huang, Z., Huang, L. L., Tan, B. W. (2012): Relationships between soil nutrient contents and soil enzyme activities in Pinus massoniana stands with different ages in Three Gorges Reservoir Area. - Chinese Journal of Applied Ecology 23: 445-451.

[12] Gonzalez-Quinones, V., Stockdale, E., Banning, N., Hoyle, F., Sawada, Y., Wherrett, A. D., Jones, D. L., Murphy, D. V. (2011): Soil microbial biomass-Interpretation and consideration for soil monitoring. - Soil Research 49: 287-304.

[13] Hamilton, C. E., Bever, J. D., Labbe, J., Yang, X. H., Yin, H. F. (2016): Mitigating climate change through managing constructed microbial communities in agriculture. Agriculture Ecosystem and Environment 216: 304-308.

[14] Hardy, R. W., Holsten, R., Jackson, E., Burns, R. (1968): The acetylene-ethylene assay for $\mathrm{N}_{2}$ fixation: laboratory and field evaluation. - Plant Physiology 43: 1185-1207.

[15] Heidarzadeh, N., Baghaee-Ravari, S. (2016): Application of Bacillus pumilus as a potential biocontrol agent of Fusarium wilt of tomato. - Archives of Phytopathology and Plant Protection 48: 13-16.

[16] Kaushal, M., Kaushal, R. (2015): Acetylene reductase activity and molecular characterization of plant growth promoting rhizobacteria to know efficacy in integrated nutrient management system. - Indian Journal of Biotechnology 14: 221-227.

[17] Kaushal, M., Wani, S. P. (2016): Plant-growth-promoting rhizobacteria: drought stress alleviators to ameliorate crop production in drylands. - Annals of Microbiology 66: 3542 .

[18] Kaushal, M., Kumar, A., Kaushal, R. (2017): Bacillus pumilus strain YSPMK11 as plant growth promoter and bicontrol agent against Sclerotinia sclerotiorum. - 3 Biotech. 7: 90.

[19] Kavino, M., Harish, S., Kumar, N., Saravanakumar, D., Samiyappan, R. (2010): Effect of chitinolytic PGPR on growth, yield and physiological attributes of banana (Musa spp.) under field conditions. - Applied Soil Ecology 45: 71-77.

[20] Khatri-Chhetri, A., Aggarwal, P. K., Joshi, P. K., Vyas, S. (2017): Farmer's prioritization of climate smart agriculture (CSA) technologies agricultural system. - Agricultural Systems 157: 184-191.

[21] Liu, N., Zhang, Y., Chang, S., Kan, H., Lin, L. (2012): Impact of grazing on soil carbon and microbial biomass in typical steppe and desert steppe of Inner Mongolia. - PloS One 7: e36434.

[22] Liu, Y., Li, R., Wang, J., Zhang, X., Jia, R., Gao, Y., Peng, H. (2017): Increased enzymatic hydrolysis of sugarcane bagasse by a novel glucose and xylose stimulated $\beta$ glucosidase from Anoxybacillus flavithermus subsp. yunnanensis E13T. - BMC Biochemistry 18: 4.

[23] Majumdar, B., Saha, A. R., Ghorai, A. K., Sarkar, S. K., Chowdhury, H., Kundu, D. K., Mahapatra, B. S. (2014): Effect of fertilizer treatments on jute (Chorchorus olitorius), microbial dynamics in its rhizosphere and residual fertility status of soil. - Indian Journal of Agricultural Sciences 84: 503-508.

[24] Nagar, N. K., Goud, V. V., Kumar, R., Kumar, R. (2016): Effect of organic manures and crop residue management on physical, chemical and biological properties of soil under pigeon pea based intercropping system. - International Journal of Science 6: 101-113.

[25] Raaijmakers, J. M., Mazzola, M. (2016): Soil immune responses. - Science 352: 1392 1393.

[26] Salamanca, E., Raubuch, M., Joergensen, R. G. (2002): Relationships between soil microbial indices in secondary tropical forest soils. - Applied Soil Ecology 21: 211-219.

[27] Santibanez, C., Varnero, M. T. (2014): Evaluation of chanar seed cake from biodiesel production as a soil amendment. - Journal of Soil Science and Plant Nutrition 14: 129138.

[28] Shaharoona, B., Arshad, M., Zahir, Z. A., Khalid, A. (2006): Performance of Pseudomonas spp. containing ACC-deaminase for improving growth and yield of maize 
(Zea mays L.) in the presence of nitrogenous fertilizer. - Soil Biology and Biochemistry 38: 2971-2975.

[29] Singh, A., Singh, V. K., Chandra, R., Srivastava, P. C. (2012): Effect of integrated nutrient management on pigeon pea-based intercropping system and soil properties in mollisols of the Tarai Region. - Journal of Indian Society of Soil Science 60: 38-44.

[30] United Nations, Department of Economic and Social Affairs, Population Division (2015): World Population Prospects: The 2015 Revision. - UN, New York.

[31] Upadhyay, A. K., Bahadur, A., Singh, J. (2012): Effect of organic manures and biofertilizers on yield, dry matter partitioning and quality traits of cabbage (Brassica oleracea var. capitata). - Indian Journal of Agricultural Sciences 82: 31-34.

[32] Vance, E. D., Brookes, P. C., Jenkinson, D. S. (1987): An extraction method for measuring soil microbial biomass C. - Soil Biology and Biochemistry 19: 703-707.

[33] Xun, W., Zhao, J., Xue, C., Zhang, G., Ran, W., Wang, B., Shen, Q., Zhang, R. (2016): Significant alteration of soil bacterial communities and organic carbon decomposition by different long-term fertilization management conditions of extremely low productivity arable soil in South China. - Environmental Microbiology 18: 1907-1917.

[34] Yang, K., Zhu, J., Zhang, M., Yan, Q., Sun, O. J. (2010): Soil microbial biomass carbon and nitrogen in forest ecosystems of Northeast China: a comparison between natural secondary forest and larch plantation. - Journal of Plant Ecology 3: 175-182. 